\title{
Орнаментальные мотивы в наскальном искусстве Казахстана
}

\section{(С) 2021 г. Швец И.Н.}

Keywords: archaeology, Kazakhstan, rock art, Eneolithic and Bronze Age, ornamental motifs, signs-symbols

Түйін сөздер: археология, Қазақстан, жартас өнері, палеометалл дәуірі, ою-өрнек сарындары, символ-белгілер

Ключевые слова: археология, Казахстан, наскальное искусство, эпоха палеометалла, орнаментальные мотивы, знаки-символы

\author{
Irina Shvets ${ }^{1}$ \\ ${ }^{1}$ Candidate of Historical Sciences (Kazakhstan), Dr. Phil. Germany (Heidelberg), \\ Independent researcher, Heidelberg, Germany. E-mail: schwezi@mail.ru
}

\section{Ornamental motifs in the rock art of Kazakhstan}

\begin{abstract}
The publication is based on the analysis of petroglyph-material from locations in Southern and South-Eastern Kazakhstan. The work attempts to identify ornamental motifs, which are part of the iconography of some petroglyphs of Karatau, Shu-Ile and Jungarian mountains. New discoveries and high-quality level of publications in recent years allows researchers to identify in the range of petroglyphs not only new subjects, techniques, but also the rarest signs/symbols and ornamental details. The object of the study was fundamentally constricted not only in terms of time, but also in terms of motif offered for consideration; ornamental motifs only on "marked" surfaces, whether it is a human body, an animal body or the contours of a certain object - weaponn, musical instrument, carriage, dwelling, etc. Ornament as a separately carved image, such as a swastika, a "wheel", a circle, sign etc. is not an object of interest in this article. Typology of ornamental motifs according to the basic principle of decorative styles allows determining the popular type of ornament in the rock art of South and South-East Kazakhstan of the Eneolithic and Bronze Age. The article gives the rarest examples of attempts to date the ornamental motifs of rock art.
\end{abstract}

For citation: Shvets I. Ornamental motifs in the rock art of Kazakhstan. Kazakhstan Archeology. 2021, 4 (14), 27-37 (in Russian). DOI: 10.52967/akz2021.4.14.27.37

\author{
Швец Ирина Николаевна ${ }^{1}$ \\ ${ }^{1}$ тарих ғылымдарының кандидаты, Германия археологиясының докторы \\ (Хайделберг), тәуелсіз зерттеуші, Хайделберг, Германия. E-mail: schwezi@mail.ru
}

\section{Қазақстанның жартасқа сурет салу өнеріндегі ою-өрнек сарындары}

Аннотация. Мақала оңтүстік және Оңтүстік-Шығыс Қазақстан петроглифтерінің материалдарын талдауға негізделген. Жұмыста Қаратау, Шу-Іле және Жетісу Алатауы жоталарының кейбір сюжеттерінің иконографиясының құрамдас бөлігі болып табылатын ою-өрнек сарындарын анықтауға әрекет жасалады. Қазақстанның жартас суреттері бойынша соңғы жылдардағы жаңа ашылымдар мен жарияланымдар сапасының жоғары деңгейі зерттеушілерге петроглифтердің репертуарында жаңа 
сюжеттерді, орындау техникасын ғана емес, сонымен қатар алғашқы өнердің осы түріндегі сирек кездесетін белгілерді/символдарды және ою-өрнектің бөлшектерін ашуға мүмкіндік береді. Ұсынылған зерттеудің тақырыбы тек уақыт шеңберімен ғана емес, сонымен қатар сюжеттік желімен де шектеледі; адамның денесі, жануардың денесі немесе белгілі бір заттың сұлбасы болсын - қару, музыкалық аспап, арба, тұрғын үй және т. б. болсын, «тірек бетінде» ою-өрнек сарындарын қарастыруды ұсынады. Мақаладан жартас өнерінің жеке бейнесі ретінде ою-өрнек, мысалы - свастика, «дөңгелек», ирелең және шеңбер алынып тасталды. Орнаменталистиканың негізгі қағидасы бойынша ою-өрнек тұрпаттамасы палеометалл дәуіріндегі оңтүстік және Оңтүстік-Шығыс Қазақстанның жартас суреттерінде танымал зер түрін анықтауға мүмкіндік береді. Мақалада жартас өнерінің ою-өрнектерімен танысу әрекеттерінің сирек кездесетін мысалдары келтірілген.

Сілтеме жасау үшін: Швец И.Н. Қазақстанның жартас өнеріндегі ою-өрнек сарындары. Қазақсстан Археологиясы. 2021. № 4 (14). 27-37-бб. (Орысша). DOI: 10.52967/akz2021.4.14.27.37

\title{
Швец Ирина Николаевна ${ }^{1}$ \\ ${ }^{1}$ кандидат исторических наук, доктор археологии Германии (Хайдельберг), независимый исследователь, Хайдельберг, Германия. E-mail: schwezi@mail.ru
}

\begin{abstract}
Аннотация. Публикация основана на анализе материала петроглифов с местонахождений Южного и Юго-Восточного Казахстана. В работе осуществляется попытка выявления орнаментальных мотивов, являющехся состовной частью иконографии некоторых сюжетов хребта Каратау, Шу-Илейских и Жетысу Алатау. Новые открытия и высокий уровень качества публикаций последних лет по наскальному искусству Казахстана, позволяет исследователям открывать в репертуаре петроглифов не только новые сюжеты, техники исполнения, но и редчайшие в данном виде первобытного искусства знаки/символы и детали орнамента. Тема предлагаемого исследования была принципиально ограничена не только временными рамками, но и сюжетными; предложены к рассмотрению орнаментальные мотивы только на ««несущей поверхности»» будь то тело человека, корпус животного или контуры определенного предмета - оружие, музыкальный инструмент, повозка, жилище и т. д. Орнамент как отдельный образ наскального искусства, например - свастика, «колесо», меандр и окружность, исключен из данной статьи. Типология орнаментальных мотивов по базовому принципу орнаменталистики позволяет определить популярный тип декора в наскальных рисунках Южного и Юго-Восточного Казахстана эпохи палеометалла. В статье приводятся редчайшие примеры попыток датировки орнаментальных мотивов наскального искусства.
\end{abstract}

Для цитирования: Швец И.Н. Орнаментальные мотивы в наскальном искусстве Казахстана. Археология Казахстана. 2021. № 4 (14). С.27-37. DOI: 10.52967/akz2021.4.14.27.37

\section{Введение}

Орнамент характеризует не только его декоративная роль, он имеет культовые и информационные функции. Его встречаемость среди рисунков наскального искусства эпохи энеолита и бронзы крайне редка и лишена для нас изначальной базовой информации изображенных реалий цвета (как маркер возраста/статуса), фактического материала изображенного (текстиль, кожа, мех и т. д. если речь идет о декоре одежды), технологии (аппликация/плетение/комбинирование). Но редкость декора в изображение одежды и тела человека, корпуса животных, делает его особо значимым в вопросах датировки и интерпретации наскального искусства. 
Так как орнамент включает в себя функции декора поверхности, нами будут рассмотренны только примеры орнаментирования на «несущей поверхности», будь то тело человека, корпус животного или контуры определенного предмета - оружие, музыкальный инструмент, повозка, жилище и т. д. Орнамент как отдельно выбитый образ, например, свастика, «колесо», меандр, окружность, будь то «загадочная картинка» или «ажурный» знак, не будут рассмотрены в данной статье, поскольку требуют специального исследования.

Орнаментальные мотивы эпохи раннего железа, выполняющие зачастую функцию сложных изобразительных текстов, также не будут рассмотрены в данной работе. Эта тема достаточно хорошо представлена в исследовательской литературе [Бейсенов, Базарбаева 2014: 597-604] и останется за рамками нашей публикации.

В предлагаемой статье предполагается остановиться на ряде вопросов: существует ли повторяемость орнаментальных элементов внутри самого наскального искусства эпохи палеометалла? Присутствуют ли аналогии орнаментальных мотивов в археологических материалах поселений и погребений? Возможна ли типология элементов орнамента в наскальном искусстве Казахстана эпохи палеометалла по базовому принципу орнаменталистики - геометрический, растительный и зооморфный?

В основе данного исследования лежит анализ материалов наскального искусства Южного и Юго-Восточного Казахстана. Выбор данных регионов не случаен и связан не только с наличием большого количества местонахождений петроглифов на данной территории, но и более качественным документированием наскальных рисунков хребтов Каратау, Шу-Илейских и Жетысу/Джунгарского Алатау [Марьяшев 2011; Марьяшев, Горячев 2011; Мургабаев 2013; Новоженов 2012а; 2012б; 2013; Рогожинский 2001; 2009, 2011a, 2011б; Сала, Деом 2005; Самашев 2006; 2012; 2013; Самашев и др. 2014; Швец 2008a; 2008б; Швец и др. 2014a; 2014б).

Характеристика и анализ материала

Выявление элементов орнамента среди петроглифов стало возможным благодаря современной методике изучения и документирования сюжетов наскального искусства. Современные технологии позволяют выявить новые детали изображенного, к которым также относятся и декоративные мотивы, и повысить информативный потенциал петроглифов.

Необходимо признать, что существует некое несоответствие между репертуаром образов, характерными для артефактов из погребений и поселений эпохи энеолита-бронзы Казахстана и репертуаром наскального искусства того же времени. Если в орнаменте керамики III-II тыс. до н.э. доминирует знаково-символическая система геометрического характера, то для наскального искусства этого же времени характерны реалистичные образы людей или животных. Нередки также изображения транспортных средств, жилищ, сцен бытового характера - перекочевка, охота, поединок. В петроглифах эпохи бронзы представлен набор образов, отражающих и сферу сакрального - «ряженые», ритуальные танцы, “coitus"сцены и т. д.

Подобная «дисгармония» в сфере художественного творчества людей эпохи энеолита-бронзы, порождает ряд версий: 
- Возможно, наскальное искусство эпохи энеолита-бронзы являлось частью сакрального, связанного с небесной сферой и культом гор, и, в связи с этим, образы наскального искусства не допускались в другие миры - мир земной и мир погребальной обрядности.

Другим возможным объяснением существующей ситуации в образовании двух «художественных репертуаров» у людей эпохи бронзы могло бы быть представление о том, что:

- Наскальное искусство и его образы рассматривалось людьми этой эпохи как примитивное, творчество и не допускалось в ритуальную сферу созидания, к которой относилось гончарное производство, ткачество, косторезное ремесло.

Найти аналогии элементам орнамента, встречающимся в наскальном искусстве, в материалах раскопок, является большой удачей. Примеров такого в мировой практике исследования первобытного искусства немного. Одним из них является материал наскальной росписи из западной Турции, местонахождение в горах Латмос. Многочисленные изображения женщин данного местонахождения изображены в юбке/фартуке (?) с орнаментом (рис. 1), встречающемся на керамике эпохи энеолита на поселении Хачилар [Peschlow-Bindokat 2003: 75].

Орнамент нижней части тела (юбка?) в изображении многочисленных женских фигур Алтая, предположительно эпохи бронзы; Калбак Таш 1 (Россия), Цагаан Салаа и Чулуут (Монголия) воспроизводит по мнению Д.В. Черемисина [Черемисин 2015: 92] одежду женских статуэток и фигур на вазах, навершиях предметов - так называемых «Бактрийских принцесс» в юбках филикли с посе- ления Гонур Депе [Царева 2012: 240249]. В бактрийско-маргианской иконографии элементы орнамента юбок статуэток Гонур Депе трактуются как «язычки» шерсти или листья-язычки [Вртанесян 2012: 300, 309] и типологически могут относиться к растительному, но в большей своей части к геометрическому орнаменту. Орнамент же на юбках женских статуэток Калбак Таш 1 (Россия), Цагаан Салаа и Чулуут (Монголия) исключительно геометрический.

А.Е. Рогожинский, датируя петроглифы гор Тарбагатай, комплекс Молдажар, использует не только стратиграфию разновременных рисунков, изображения реалии времени, но и орнаментальные мотивы на корпусе животных, что позволяет ему говорить о датировке этих рисунков эпохой бронзы [Рогожинский 2009: 62]. Орнамент на телах животных петроглифов Молдажара относится к геометрическому типу.

Орнамент является составной частью так называемого скелетного стиля, подобным образом изображались не только некоторые антропоморфные фигуры, но и зооморфные. Антропоморфные гравюры, тела которых изображены в виде скелета, могли представлять собой изображения шаманов. Наибольшая их концентрация наблюдается в Восточной Сибири, в Казахстане они встречаются редко. Антропоморфные фигуры в скелетном стиле выявлены среди наскальных рисунков Тамгалы и Терса в Юго-Восточном Казахстане. Скелетная выбивка этих рисунков в тоже время определяется как геометрический орнамент, состоящий из абстрактных форм - прямые, ломаные, сетчатопересекающиеся линии.

В «скелетном» стиле изображались многие зооморфные фигуры. Та- 


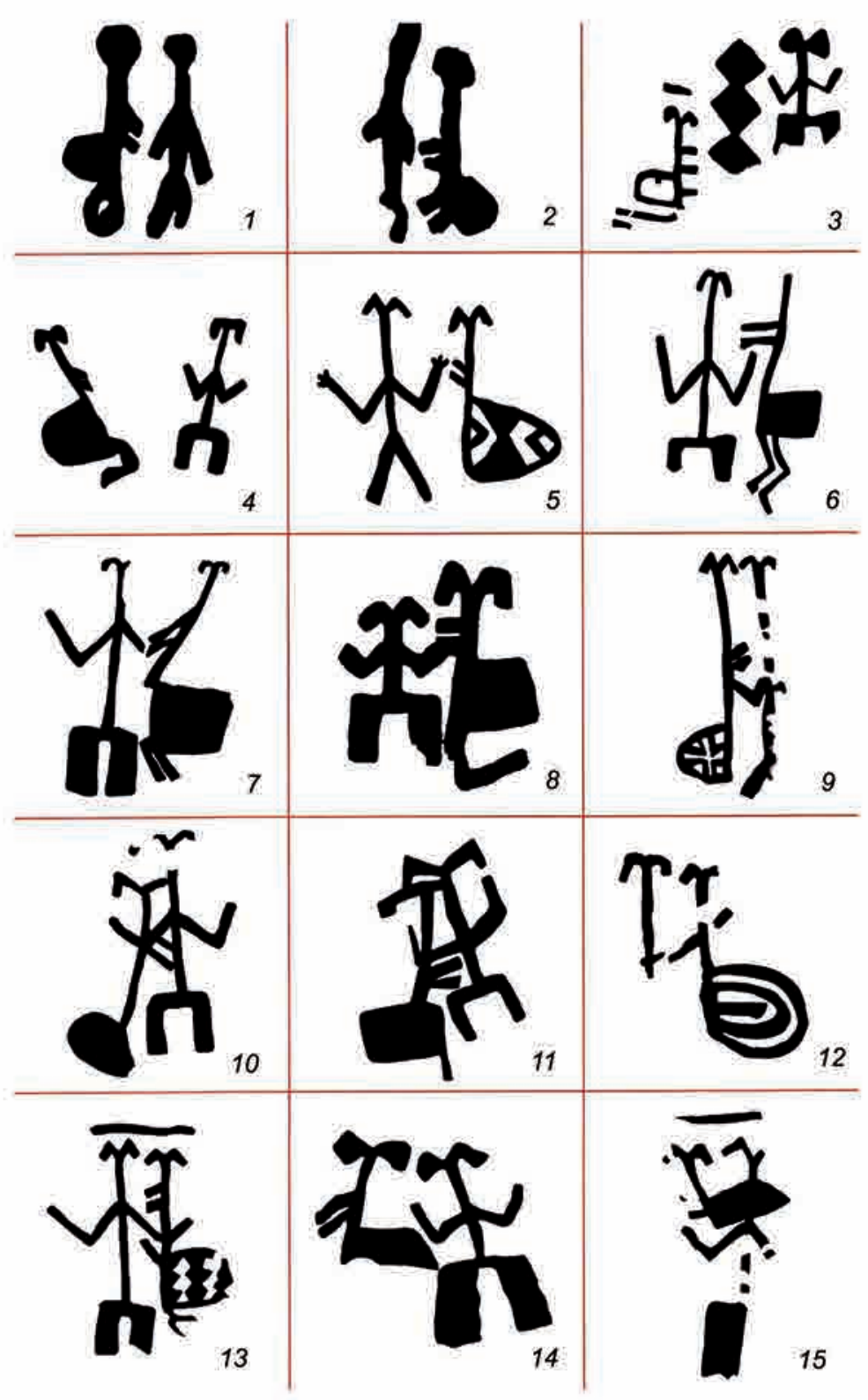

Рис. 1. Изображение антропоморфных пар - мужчина и женщина.

Местонахождение Латмос, Западная Турция (по: [Peschlow-Bindokat 2003: Abb. 36])

1-сур. Антропоморфтық жұп - еркек пен әйел бейнесі. Табылған жері Латмос, Батыс Түркия ( [Peschlow-Bindokat 2003: Abb. 36] бойынша)

Fig. 1. Image of anthropomorphic couples - a man and a woman. Rock art site Latmos, Western Turkey (by: [Peschlow-Bindokat 2003: III. 36]) 
ким образом, древний художник мог показывать масть животных - коров и быков. Подобный декор на телах оленей и верблюдов предполагает другое объяснение. Это могло бы быть копированием на скалах аппликационных и ажурных изделий мелкой пластики, характерных для эпохи раннего железа, что подразумевает датировку данных изображений животных концом эпохи бронзы-ранним железным веком. Необходимо отметить, что «скелетный» стиль, был популярен в первобытном искусстве Центральной Азии, а также на территории древнего Китая, Южной и Северной Америки, и Древнего Востока. Изображения животных, особенно оленей и верблюдов с заштрихованным телом встречаются и в раннем железном веке, что свидетельствует о популярности данной изобразительной традиции. Е.Г. Фурсикова объясняет это сходство преемственностью отдельных элементов окуневского искусства в скифо-сакский период [Фурсикова 2002: 250].

При исполнении ряда зооморфных фигур местонахождения Сауыскандык, хребет Каратау, также была применена, так называемая, скелетная выбивка, когда корпус животного был разделен прямыми, перпендикулярными, горизонтальными или косыми линями [Самашев и др. 2014: рис. 160, 249, 262, 290-307]. В петроглифах Сауыскандыка, имеются огромные изображения верблюдов, тела которых покрыты сеткой орнамента. Размеры, патина и иконография данных изображений [Самашев и др. 2014: рис. 156] предполагают их датировать эпохой энеолита. В вопросах датировки изображений животных в скелетном стиле важен комплекс характеристик патина, иконография, изображенные реалии и т. д.
Новым для рисунков Южного Казахстана можно считать пример выбивки корпуса животных (в основном, быков) по контуру, возможно, с дальнейшим шлифованием и полированием изображения тела животного и исполнением на нем в технике барельефа одного или нескольких кругов [Самашев и др. 2014: рис. 249, 289, 294, 295, 308]. Интересными и редкими экземплярами являются изображения незаконченных фигур животных, позволяющие проследить технику нанесения рисунка. Так, некоторые хорошо узнаваемые части тела животных (в основном, верблюдов) - шея и голова, ноги и т. д., демонстрировали по контуру еле заметный современному зрителю легко процарапанный контур фигуры, который в дальнейшем должен был заполняться выбивкой в соответствующей технике.

В петроглифах гор БалаСауыскандык изображение быка демонстрирует особое многообразие выбивки и вариаций в изображении таких деталей как рога, хвост, корпус. Большинство изображений быков в петроглифах гор БалаСауыскандык датируется, вероятнее всего, эпохой энеолита-ранней бронзы. Именно с этим периодом связаны наиболее тщательно исполненные изображения данных животных. Bсе они имеют массивный корпус и мощные - серповидные или же выполненные в виде кольца, направленные вперед, а также волнообразные рога. Хвосты животных имеют форму шара, листа на конце или изображены одной полосой. Корпус быка чаще показан сплошной выбивкой, встречается также скелетная/ажурная техника, а также элементы барельефа.

Изображения быков, датируемые эпохой энеолита-ранней бронзы и характерные для синхронных куль- 
Швец И.Н. Орнаментальные мотивы в наскальном искусстве Казахстана

тур соседних регионов, были связаны, скорее всего, с его экономической и ритуальной ролью у племен данной эпохи. Для более поздних периодов истории региона это животное теряет свое былое значение. Это связано и со сменой хозяйственной деятельности, и с исчезновением дикого быка в степях Евразии - в прошлом одной из крупнейших охотничьих добыч, и соответственное его смещение в культах и верованиях населения.

Среди петроглифов Сауыскандыка имеются редкие изображения упряжных быков с небольшими колечками на кончике морды, предназначенные для крепления ремней управления. Через такие кольца в носу тяглового быка пропускались ремни или веревка, с помощью которых достаточно эффективно осуществляли контроль и управление. Во многих случаях хорошо видно, что ремнивожжи примыкают к кончикам морды животных: в Саймалы-Таше (Киргизия), Байконуре (Центральный Казахстан), Ешкиольмесе (Юго-Восточный Казахстан). Такой способ управления с помощью кольца в носу многократно запечатлен среди окуневских изображений быков в Южной Сибири.

Быков из урочища Сауыскандык сближает с саймалыташскими также и трактовка кистей хвоста в виде треугольной геометрической фигуры и присутствие в композиции хвостатых ряженых персонажей, а также малые габариты колес повозок. Сходства на этом кончаются, сауыскандыкские образцы по сравнению с саймалыташскими более реалистичны, динамичны и в ряде случаев отмечены солярными символами-кольцами, круглыми точками, решетчатыми знаками и др. Репрезентативную группу изображений быков из Сауыскандыка (Каратау) и Жетысу (Юго-Восточный
Казахстан), составляют те, у которых корпуса разрисованы различными геометрическими узорами, «клетками», кругами, точками, волнистыми и зигзагообразными линиями, расположенными как вертикально, так и горизонтально. В декорировании подобными «узорами» туловища быков пока не улавливается какая-либо система или числовая характеристика, поэтому каждая разрисованная фигура отличается своей индивидуальностью и неповторимостью. Нет хронологического разрыва и между «ажурными» и обычными фигурами быков; они чаще встречаются вместе и поэтому такой способ оформления корпуса животных нужно рассматривать, видимо, с точки зрения религиозных воззрений древних людей и как семантическое явление.

Природа такого рода маркировок абстрактно-геометрическими узорами изображений животных в эпоху бронзы не вполне понятна. Они могут быть квалифицированы как обычный декоративный элемент или, в ряде случаев, как попытка древнего мастера необычным художественным приемом передать особенности естественной окраски шерсти животных.

В петроглифах Саяно-Алтайской провинции, включая Монгольский Алтай, фигуры быка с разрисованным туловищем встречаются реже, чем в северо-тяньшанской. Изображения быка/яка, корпус которого разделен вертикальными линиями, присутствуют в памятниках Северной Монголии.

Стилистические параллели изображениям быков Сауыскандыка в памятниках Окуневской культуры, среди петроглифов эпохи бронзы Саймалы-Таш (Кыргызстан), а также техника, патина и сохранность рисунков позволяют датировать данный 
зооморфный образ Сауыскандыка в большей части концом III - началом II тыс. до н.э.

Изображения быков были связаны, скорее всего, с его значительной экономической и ритуальной ролью у племен данной эпохи. Этим же можно обьяснить и особое внимание к изображению данного животного. Выбивка на теле быков представляет собой также геометрический орнамент, состоящий из абстрактных форм - прямые, ломаные, сетчатопересекающиеся линии, круги, углы и т. д. Для более поздних периодов истории региона это животное теряет свое былое значение. Это связано и со сменой хозяйственной деятельности, и с исчезновением дикого быка в степях Евразии - в прошлом одной из крупнейших охотничьих добыч, основным тягловым животным, и соответственное его смещение в культах и верованиях населения.

\section{Заключение}

Представленный материал, позволяет, хотя и довольно обобщенно, выявить определенную динамику присутствия, изменения и преемственности орнамента в наскальном искусстве Казахстана эпохи энеолитабронзы. Исследованный материал петроглифов Казахстана предполагает, что орнаментальные мотивы выполняли как сакральные, так и декоративные функции посредством рисунка. На сегодняшний день в петроглифах Казахстана эпохи энеолита-бронзы возможно выделить только геометрический тип орнамента, состоящий из абстрактных форм - прямые, ломаные, сетчато-пересекающиеся линии, круги, углы и т. д. Если репертуар образов наскального и прикладного искусства эпохи палеометалла сильно различался, то в вопросах орнаментирования «несущей/оконтуренной поверхности» мы встречаемся с определенной тенденцией - доминированием геометрических орнаментальных мотивов. Геометрический, состоящий из абстрактных форм орнамент, будет являться основным, «несущим» компонентом прикладного искусства населения Казахских степей и в последующие исторические эпохи. В меньшей степени геометрические орнаментальные мотивы присутствуют в искусстве звериного стиля ранних кочевников степей Евразии, где зооморфные мотивы являются доминирующими и представляют из себя не только часть декора, но и определенный код визуализации древних мифов.

Художественное решение произведения казахских ремесел отмечается «необыкновенной вариативностью, подвижностью декоративных решений». Орнамент, также, как и выразительность формы, цветовая гамма, техника исполнения, усиливал значимость предметов традиционного казахского искусства [Тохтабаева 2008: 25, 106]. Геометрический орнамент, наряду с зооморфным, космогоническим, растительным и т.д. относится, по мнению Ш.Ж. Тохтабаевой, к знаковым казахским орнаментальным мотивам [Тохтабаева 2008: 28].

\section{ЛИТЕРАТУРА}

1. Байпаков K.M., Марьяшев А.Н. Петроглифы в горах Кульжабасы. Алматы: Print-S, 2004. 22 с. 88 ил.

2. Бейсенов А.З., Базарбаева Г.А. Орнамент в культуре саков Центрального Казахстана // Известия Самарского научного центра РАН. Археология и этнография. 2014. T. 16, № 3 (2). C. 597-604. 
Швец И.Н. Орнаментальные мотивы в наскальном искусстве Казахстана

3. Вртанесян Г.С. Составные статуэтки эпохи бронзы // Труды Маргианской археологической экспедиции. Т. 6. Памяти В.И. Сарианиди / Гл. ред. Н.А. Дубова. М.: Старый сад, 2016. С. 291-313.

4. Марьяшев А.Н. Наскальные изображения Казахстана: итоги 20 -летнего изучения и проблемы // Археология Казахстана в эпоху Независимости: итоги и перспективы. М-лы междунар. науч. конф., посвящ. 20-летию Независимости Республики Казахстан и 20-летию Института археологии им. А.Х. Маргулана (г. Алматы, 12-15 декабря 2011 г.). / Гл. ред. Б.А. Байтанаев, отв. ред. А.З. Бейсенов. Алматы: ИА КН МОН РК, 2011. T. 1. С. 36-40.

5. Марьяшев А.Н., Горячев А.А. Итоги изучения памятников эпохи бронзы Жетысу // Свидетели тысячелетий: археологическая наука Казахстана за 20 лет / Гл. ред. Б.А. Байтанаев, отв. ред. А.З. Бейсенов. Алматы: ИА КН МОН РК, 2011. С. 313-337.

6. Мургабаев С.С. Проблемы хронологии и культурных связей ранних петроглифов Каратау // Научное обозрение Саяно-Алтая. 2013. № 1 (5). С. 52-65.

7. Новоженов B.A. Чудо коммуникации и древнейший колесный транспорт Евразии. M.: Tayc, 2012a. 500 c.

8. Новоженов B.A. Заметки по этнокультурной истории племен эпохи бронзы Центральной Азии // Материалы и исследования по культурно-генетическим процессам на территории древнего и средневекового Казахстана. Полевые материалы и исследования кафедры археологии, этнологии и музеологии КазНУ им. ал-Фараби / Отв. ред. Р.С. Жуматаев. Алматы: Казак университеті, 2012б. Вып. 2. С. 44-67.

9. Новоженов B.A. Изобразительные коммуникации населения УралоКазахстанских степей в эпоху энеолита и ранней бронзы // Творчество в археологическом и этнографическом измерении: сб. науч. тр. / Гл. ред. Н.А. Томилов, отв. ред. М.А. Корусенко. Омск: Изд. дом «Наука», 2013. С. 185-197.

10. Рогожинский A.E. Изобразительный ряд петроглифов эпохи бронзы святилища Тамгалы // ИАС. 2001. Вып. 2. С. 7-44.

11. Рогожинский A.E. Наскальные изображения «солнцеголовых» из Тамгалы в контексте изобразительных традиций бронзового века Казахстана и Средней Азии // Материалы и исследования по археологии Кыргызстана. 2009. Вып. 4. С. 53-65.

12. Рогожинский A.E. Образы и реалии древнеземледельческой цивилизации Средней Азии в наскальном искусстве эпохи бронзы Южного Казахстана и Семиречья // Наскальное искусство в современном обществе: м-лы междунар. науч. конф. / Отв. ред. О.С. Советова. Кемерово: САИПИ, 2011а. С. 87-99.

13. Рогожинский A.Е. Петроглифы археологического ландшафта Тамгалы. Алматы: Signet Print, 2011б. 342 c.

14. Сала Р., Деом Ж.-М. Наскальные изображения Южного Казахстана. Алматы; ЛабГеоархео, 2005. 150 с.

15. Самашев 3. Петроглифы Казахстана. Алматы: Өнер, 2006. 200 с.

16. Самашев 3. Наскальные изображения Жетысу. Баянжурек. Астана: ФИА КН МOH РК, 2012. 240 c.

17. Самашев 3. Древнее искусство. Т. 1. Алматы: Елнур, 2013. 240 с.

18. Самашев 3., Мургабаев С., Елеуов М. Петроглифы Сауыскандыка. Астана: ФИА КН МОН РК, 2014. 374 с.

19. Тохтабаева Ш.Ж. Шедевры Великой степи. Алматы; «Дайк-Пресс», 2008. $239 \mathrm{c}$.

20. Фурсикова Е.Г. О стилистических параллелях в окуневском и скифо-сибирском искусстве // Степи Евразии в древности и средневековье: м-лы науч.-практ. конф., посвящ. 100-летию со дня рожд. М.П. Грязнова (СПб., 11-16 марта 2002 г.) / Отв. ред. Ю.Ю. Пиотровский. СПб.: ГосЭрмитаж, 2002. Кн. 2. С. 247-251.

21. Царева Е.Г. Филикли: к истории узелкового ткачества в Центральной Азии (по материалам Месопотамии и Туркменистана) // Труды Маргианской археологической экспедиции. Т. 6. Памяти В.И. Сарианиди / Гл. ред. Н.А. Дубова. М.: Старый сад, 2016. C. $240-249$.

22. Черемисин Д.В. Об интерпретации одного сюжета в петроглифах Алтая эпохи бронзы // Искусство Бронзового века: м-лы междунар. симпозиума (г. Штральзунд, 15- 
19 апреля 2013 г.) / Ред. С. Хансен, В.И. Молодин. Новосибирск-Берлин: Новосибирский гос. ун-т; Германский археологический ин-т, 2015. С. 79-93.

23. Швец И.Н. Об антропоморфных изображениях казахстанских петроглифов эпохи бронзы // Таинство этнической истории древнейших номадов степной Евразии. Коллективная монография памяти Е.Е. Кузьминой / Гл. ред. А.В. Епимахов. Алматы: Остров Крым, 2014а. С. 294-299.

24. Швеи И.Н. Антропоморфные изображения с посохом в наскальном искусстве Южного Казахстана // Восхождение к вершинам археологии: сб. м-лов междунар. науч. конф. «Древние и средневековые государства на территории Казахстана», посвящ. 90-летию со дня рождения К.А. Акишева (г. Алматы, 26-28 мая 2014 г.) / Гл. ред. Б.А. Байтанаев, отв. ред. К.М. Байпаков. Алматы: ИА КН МОН РК, 2014б. С. 157-165.

25. Швец И., Самашев 3., Мургабаев С., Бедельбаева М. Петроглифы местонахождения Сауыскандык: к проблеме культурных контактов древнего населения Евразии // VII исторические чтения памяти М.П. Грязнова: сб. науч. трудов / Ред. С.Т. Татауров. Омск: ОмГУ, 2008а. С. 342-347.

26. Швеи И., Самашев 3., Мургабаев С., Бедельбаева М. Некоторые итоги изучения местонахождения петроглифов Сауыскандык в Южном Казахстане // Вестник КарГУ. Сер. история, философия, право. 2008б. № 4 (52). С. 22-26.

27. Peschlow-Bindokat A. Frühe Menschenbilder. Die prähistorischen Felsmalereien des Latmos-Gebirges (Westtürkei). Mainz: Philipp von Zabern, 2003. 108 s.

\section{REFERENCES}

1. Baipakov, K. M., Maryashev, A. N. 2004. Petroglify v gorakh Kulzhabasy (Petroglyphs in the Kulzhabasy mountains). Almaty: "Print-S” Publ. (in Russian).

2. Beisenov, A. Z, Bazarbaeyva, G. A. 2014. In: IIzvestiya Samarskogo nauchnogo tsentra Rossiyskoy akademii nauk. Arkheologiya i etnografiya (Proceedings of the Samara Scientific Center of the Russian Academy of Sciences. Archaeology and ethnography), vol. 16, no. 3 (2), 597-604 (in Russian).

3. Vrtanesyan, G. S. 2016. In: Dubova, N. A. (ed.). Trudy Margianskoy arkheologicheskoy ekspeditsii. T. 6. Pamyati V.I. Sarianidi (Proceedings of the Margian Archaeological expedition. Vol. 6. In memory of Sarianidi, V. I.). Moscow: "Staryy sad" Publ., 291-313 (in Russian).

4. Maryashev, A. N. 2011. In: Baitanayev, B. A., Beisenov, A. Z. (eds.). Arkheologiya Kazakhstana $v$ epokhu nezavisimosti: itogi i perspektivy (Archeology of Kazakhstan in the era of Independence: results and prospects). Almaty: A.Kh. Margulan Archaeology Institute, vol. 1, 36-40 (in Russian).

5. Maryashev, A. N., Goryachev, A. A. 2011. In: Baitanayev, B. A. (ed.). Svideteli tysyacheletiy: arkheologicheskaya nauka Kazakhstana za 20 let. Almaty: A.Kh. Margulan Archaeology Institute, 313-337 (in Russian).

6. Murgabayev, S. S. 2013. In: Nauchnoye obozreniye Sayano-Altaya, 1 (5), 52-65 (in Russian).

7. Novozhenov, V.A. 2012a. In: Kuzmina, Ye. (ed.). Chudo kommunikatsii i drevneyshiy kolesnyy transport Yevrazii (The miracle of communication and the oldest wheeled transport of Eurasia). Moscow: “Taus” Publ. (in Russian).

8. Novozhenov, V. A. 2012b. In: Zhumatayev, R. S. (ed.). Materialy i issledovaniya po kulturno-geneticheskim protsessam na territorii drevnego i srednevekovogo Kazakhstana (Materials and research on cultural and genetic processes on the territory of ancient and medieval Kazakhstan). Vol. 2. Almaty: "Kazakh University" Publ., 44-67 (in Russian).

9. Novozhenov, V.A. 2013. In: Korusenko, M.A.(ed.) Tvorchestvovarkheologicheskom i etnograficheskom izmerenii (Creativity in the archaeological and ethnographic dimension). Omsk: "Nauka” Publ., 185-197 (in Russian).

10. Rogozhinskiy, A. Ye. 2001. In: Maryashev, A. N., Motov, Yu. A. (eds.) Istoriya i arkheologiya Semirechiya (History and archeology of Semirechye), 2, 7-44 (in Russian). 
11. Rogozhinskiy, A. Ye. 2009. In: Materialy i issledovaniya po arkheologii Kyrgyzstana (Materials and research on archeology of Kyrgyzstan), 4, 53-65 (in Russian).

12. Rogozhinskiy, A. Ye. 2011a. In: Sovetova, O. S (ed.) Naskalnoye iskusstvo $v$ sovremennom obshchestve (Rock art in modern society). Kemerovo: Siberian Association of Researchers of Prehistory Art, 87-99 (in Russian).

13. Rogozhinskiy, A. Ye. 2011b. Petroglify arkheologicheskogo landshafta Tamgaly (Petroglyphs of the archaeological landscape of Tamgaly). Almaty: "Signet Print” Publ. (in Russian).

14. Sala, R., Deom, Zh.-M. 2005. Naskalnyye izobrazheniya Yuzhnogo Kazakhstana (Rock paintings of Southern Kazakhstan). Almaty: "LabGeoarkheo" Publ., (in Russian).

15. Samashev, Z. 2006. Petroglify Kazakhstana (Petroglyphs of Kazakhstan). Almaty: "Oner" Publ. (in Russian).

16. Samashev, Z. 2012. Naskalnyye izobrazheniya Zhetysu. Bayanzhurek (Rock carvings of Zhetysu. Bayanzhurek). Astana: Branch of the A.Kh. Margulan Archaeology Institute (in Russian).

17. Samashev, Z. 2013. Drevneye iskusstvo (Ancient art), vol. 1. Almaty: "Yelnur" Publ. (in Russian).

18. Samashev, Z., Murgabayev, S., Yeleuov, M. 2014. Petroglify Sauyskandyka (Petroglyphs of Sauiskandyk). Astana: Branch of the A.Kh. Margulan Archaeology Institute (in Russian).

19. Tokhtabayeva, Sh. Zh. 2008. Shedevry Velikoy stepi (Masterpieces of the Great Steppe). Almaty: "Dayk-Press” Publ. (in Kazakh, Russian).

20. Fursikova, Ye. G. 2002. In: Piotrovskiy, Yu. Yu. (ed.). Stepi Yevrazii v drevnosti i srednevekovie (Steppes of Eurasia in antiquity and the Middle Ages), vol. 2. Saint Petersburg: State Hermitage, 247-251 (in Russian).

21. Tsareva, Ye. G. 2016. In: Dubova, N. A. (ed.). Trudy Margianskoy arkheologicheskoy ekspeditsii. T. 6. Pamyati V.I. Sarianidi (Proceedings of the Margian Archaeological expedition. Vol. 6. In memory of Sarianidi, V. I.). Moscow: "Staryy sad” Publ., 240-249 (in Russian).

22. Cheremisin, D. V. 2015. In: Hansen, S., Molodin, V. I (eds.) Iskusstvo Bronzovogo veka (The Art of the Bronze Age). Novosibirsk-Berlin: Novosibirsk State University; German Archaeological Institute, 79-93 (in Russian).

23. Shvets, I. N. 2014a. In: Yepimakhov, A. V. (ed.) Tainstvo etnicheskoy istorii drevneyshikh nomadov stepnoy Yevrazii (The mystery of the ethnic history of the oldest nomads of steppe Eurasia). Almaty: “Ostrov Krym” Publ., 294-299 (in Russian).

24. Shvets, I. N. 2014b. In: Baitanayev, B. A., Baipakov, K. M. (eds.). Voskhozhdeniye $k$ vershinam arkheologii (Ascent to the heights of archeology). Almaty: A.Kh. Margulan Archaeology Institute, 157-165 (in Russian).

25. Shvets, I., Samashev, Z., Murgabayev, S., Bedelbayeva, M. 2008a. In: Tataurov, S. T. (ed.). VII istoricheskiye chteniya pamyati M.P. Gryaznova ( $7^{\text {th }}$ historical readings in memory of M.P. Gryaznov). Omsk: Omsk State University, 342-347 (in Russian).

26. Shvets, I., Samashev, Z., Murgabayev, S., Bedelbayeva, M. 2008b. In: Vestnik KarGU. Ser. istoriya, filosofiya, pravo (Bulletin of Karagandy State University. Ser. history, philosophy, law), 4 (52), 22-26 (in Russian).

27. Peschlow-Bindokat, A. 2003. Frühe Menschenbilder. Die prähistorischen Felsmalereien des Latmos-Gebirges (Westtürkei). Mainz: "Philipp von Zabern” Publ. (in German).

Мүдделер қақтығысы туралы ақпаратты ашу. Автор мүдделер қақтығысының жоқтығын мәлімдейді.

/ Раскрытие информации о конфликте интересов. Автор заявляет об отсутствии конфликта интересов.

/ Disclosure of conflict of interest information. The author claims no conflict of interest.

Мақала туралы ақпарат / Информация о статье / Information about the article.

Редакцияға түсті / Поступила в редакцию / Entered the editorial office: 12.10.2021.

Рецензенттер мақұлдаған / Одобрено рецензентами / Approved by reviewers: 27.10.2021.

Жариялауға қабылданды / Принята к публикации / Accepted for publication: 27.10.2021. 